DEPARTMENT OF THE INTERIOR

FrankIIN K. LANE, Secretary -

United States Geological Survey

George Otis Smith, Director

\title{
Bulletin 691
}

\section{CONTRIBUTIONS T0 ECONOMIC GEOLOGY}

(SHORT PAPERS AND PRELIMINARY REPORTS)

\section{8}

\section{PART II.-MINERAL FUELS}

DAVID WHITE, G. H. ASHLEY, AND M. R. CAMPBELL GEOLOGISTS IN CHARGE

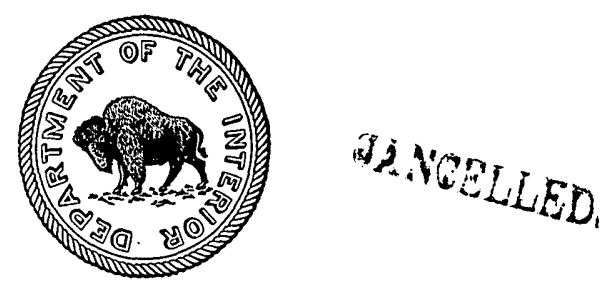

WASHINGTON

GOVERNMENT PRINTING OFFIOE 



\section{CONTENTS.}

[The letters in parentheses preceding the titles are those used to designate the papers for advance publication.]

(A) The structure of parts of the central Great Plains, by N. H. Darton (pub-

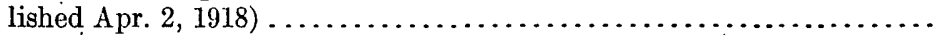

(B) Oil shale of the Uinta Basin, northeastern Utah, by D. E. Winchester

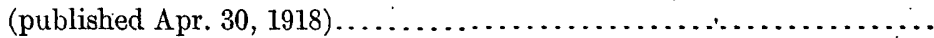

(B) Results of dry distillation of miscellaneous shale samples, by D. E. Win-

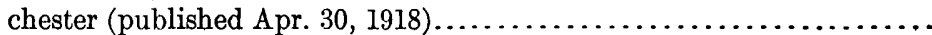

(C) Geologic structure of the northwestern part of the Pawhuska quadrangle, Oklahoma, by K. C. Heald (published Feb. 7, 1918) ................

(D) Geology and oil and gas prospects of the Lake Basin field, Montana, by E.

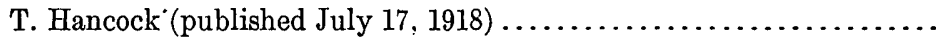

E) Oil and gas geology of the Birch Creek-Sun River area, northwestern Montana, by Eugene Stebinger (published 1919).................

(F) Anticlines in a part of the Musselshell Valley, Musselshell, Meagher, and Sweetgrass Counties, Mont., by C. F. Bowen (published 1919)..........

(G) The Nesson anticline, Williams County, N. Dak., by A. J. Collier (pub-

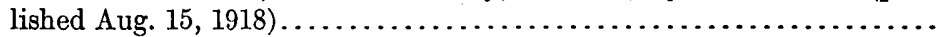

(H) Geology and oil prospects of the Salinas Valley-Parkfield area, California,

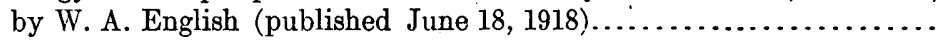

(I) The Santo Tomas cannel coal, Webb County, Tex., by G. H. Ashley (pub-

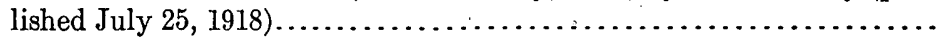

(J) Asphalt deposits and oil conditions in southwestern Arkansas, by H. D.

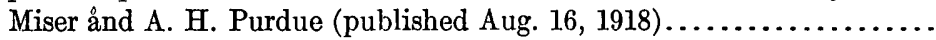

(K) Coal south of Mancos, Montezuma County, Colo., by A. J. Collier (pub-

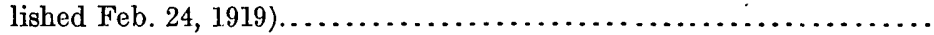

(L) Geology of the Lost Creek coal field, Morgan County, Utah, by F. R. Clark

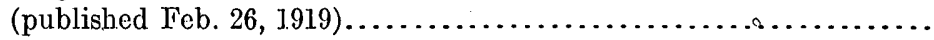

(M) Structure and oil resources of the Simi Valley, southern California, by

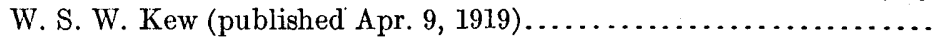

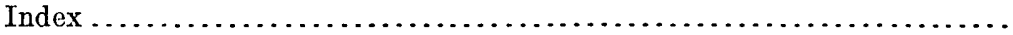

Page.

\section{ILLUSTRATIONS.}

Plate I. Map of central Great Plains.

II. Outcrop of chalk of Niobrara formation in southwestern part of Shannon County, S. Dak.

III. Diagram showing structure of parts of Fall River and Shannon

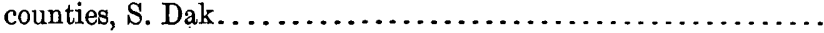

IV. Sections across southeastern Colorado.....................

V. $A$, Asphaltic sandstone near Watson, Utah; $B$, Concretionary sand-

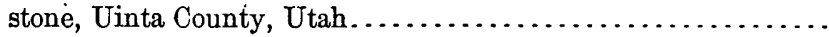

VI. $A$, Desolation Canyon of Green River, Utah; $B$, Gilsonite vein below oil shale near Watson, Utah..................... 
Plate VII. $A$, Green River formation on north side of Argyle Canyon, Utah; Page. $B$, Green River formation on west side of Parachute Creek, Colo..

VIII. Fossil vegetable matter of oil shale of Green River formation (gen-

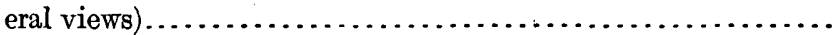

IX. Fossil vegetable matter of oil shale of Green River formation (de-

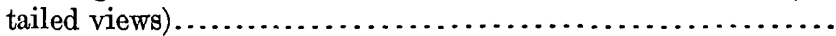

X. $A$, Oil shale northeast of Watson, Utah; $B$, Thin-bedded oil shale..

XI. Abandoned shale retort near Juab, Utah...................

XII. Map showing distribution of oil shale in Uinta Basin, Utah. In pocket.

XIII. Map of a portion of the Pawhuska quadrangle, Okla., showing topography and structure............................

XIV. Records of wells drilled in the northwest corner of the Pawhuska quadrangle, Okla., compared with the upper portion of the record of the Caney deep well and the general stratigraphic section of the Pennsylvanian rocks in the Independence quadrangle, Kans.

XV. Records of deep wells at Caney, Neodesha, and Iola, Kans., showing the character of the upper part of the pre-Pennsylvanian rocks of southeastern Kansas.

XVI. Geologic map of Lake Basin field, Mont................ In pocket.

XVII. Stratigraphic sections in north-central Wyoming and south-central Montana, showing the principal sands in the Colorado shale and the sands that yield oil and gas.................... In pocket.

XVIII. Diagrammatic representation of the nonpersistence of lithologic units in the Lake Basin field, Mont.....................

XIX. $A$, False-bedded Eagle sandstone cut off by a fault in the SE. $\frac{1}{4}$ sec. 23, T. 3 N., R. 22 E., Mont.; $B$, The Judith River formation as it is exposed in the very much dissected area $1 \frac{1}{2}$ miles south of Acton, Mont

XX. $A$, Sandstone at top of ridge in Bearpaw shale near section line between secs. 33 and 34, T. 2 N., R. 21 E., Mont.; B, Basal portion of ridge-forming sandstone in Bearpaw shale near middle of sec. 35, T. 2 N., R. 21 E., Mont.......................

XXI. $A$, View, looking southeast from point of Eagle sandstone near
the northeast corner of sec. 9, T. 3 N., R. 20 E., Mont.; $B$,
Northward-sloping hillside where fault cuts through the Eagle,
Claggett, and Judith River sandstones into Hailstone Basin,
Mont..............................................
XXII. $A$, Small thrust fault in Eagle sandstone in the SE. $\frac{1}{4}$ sec. 18, T.
3 N., R. 23 E., Mont.; $B$, Fault in southwest corner of sec. 7 ,
T. 2 N., R. 24 E., Mont...................................
XXIII. Faulted anticline of Eagle sandstone, looking southeast from a

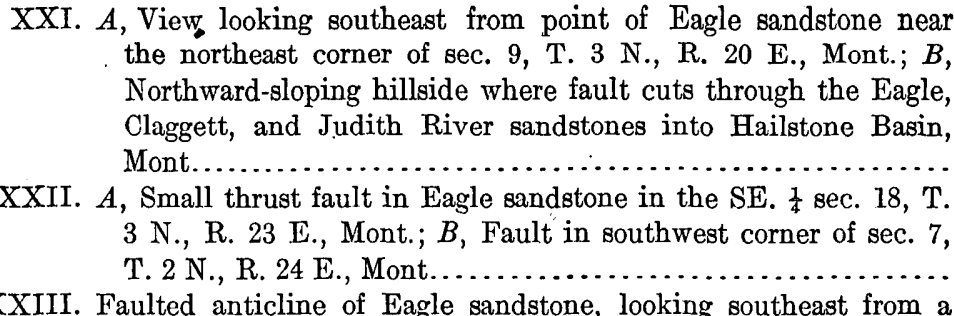

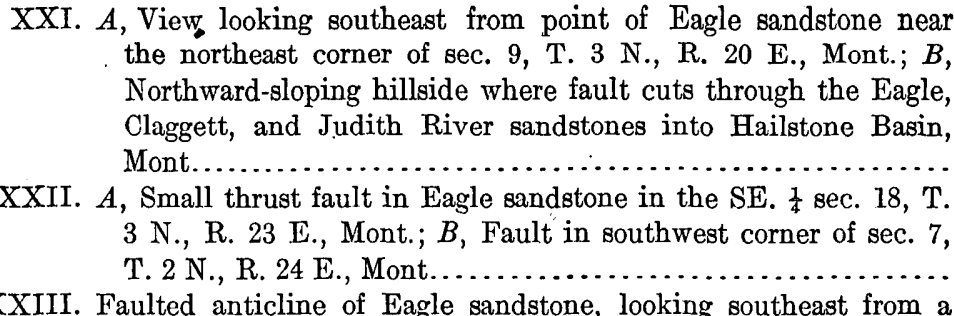

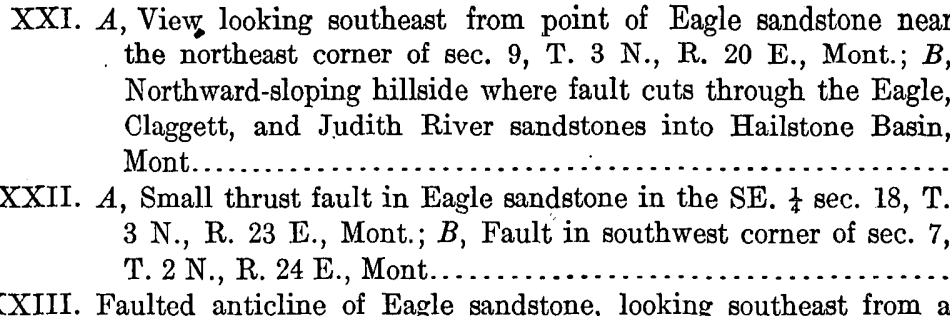

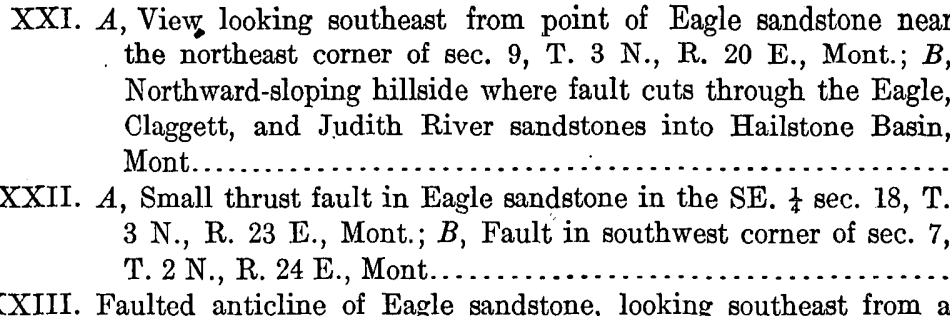

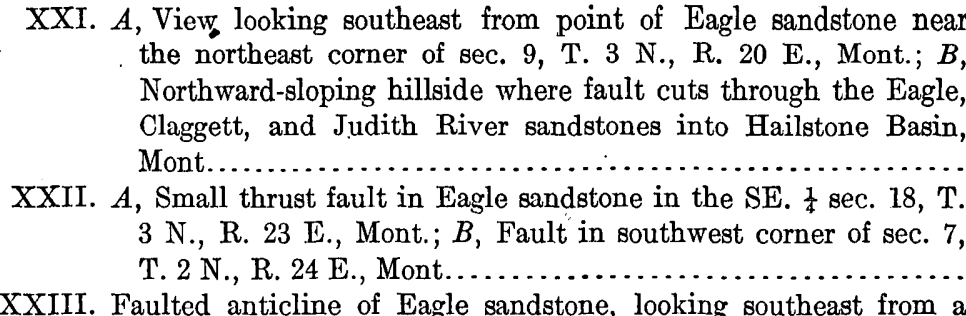

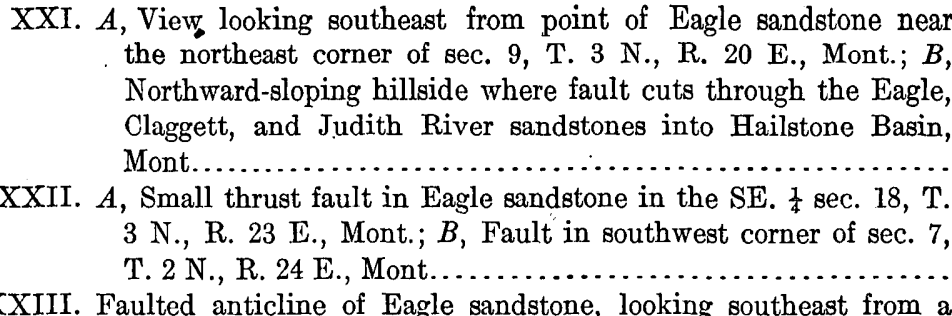

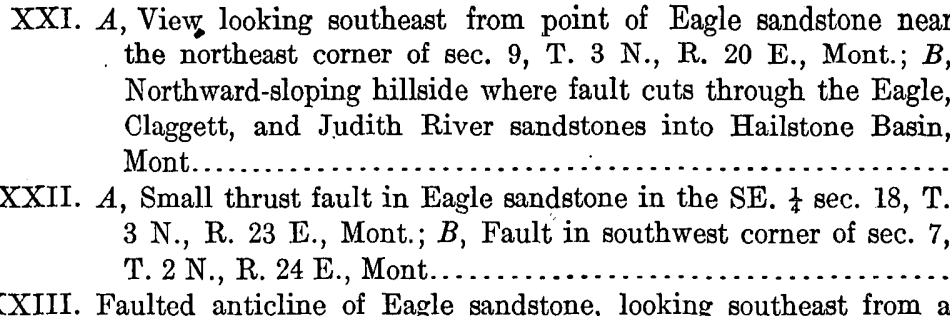

XXIII. Faulted anticline of Eagle sandstone, looking southeast from a
point on the sandstone in the Bearpaw shale in the northwest corner of sec. 16, T. 2 N., R. 25 E., Mont...................
Geologic map and sections of Birch Creek-Sun River area,

XXIV. Geologic map and sections of Birch Creek-Sun River area, Mont....................................... In pocket.

XXV. Geologic map and sections of a part of the Musselshell Valley,

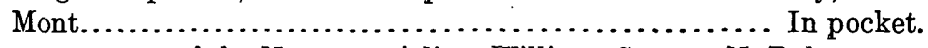

XXVI. Structure map of the Nesson anticline, Williams County, N. Dak., and sections showing lignite beds of the Fort Union formation exposed near the anticline......................... 212

XXVII. Geologic map of middle Salinas Valley, Cal............... In pocket.

XXVIII. Geologic map of Parkfield district, Cal.................. 220

XXIX. Sketch map of productive portion of Santo Tomas coal field,

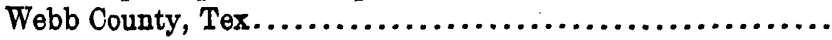


Plate XXX. $A, B$, Physiographic features of Santo Tomas coal field, Tex....

XXXI. $A, B$, Views showing character of rocks in Santo Tomas coal field,

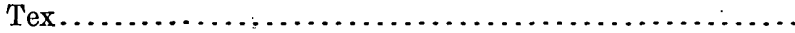

XXXII. $A, B$, Views of mines in Santo Tomas coal field, Tex .........

XXXIII. Geologic map of part of southwestern Arkansas, showing the location of the asphalt deposits on the north border of the Gulf

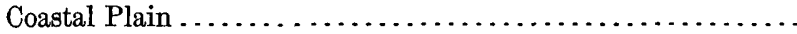

XXXIV. Map showing the exposures of coal of Mesaverde age near Mancos, Colo.

XXXV. A, View up.Weber Canyon, Colo., from its junction with Mancos Canyon; $B$, View down Mancos Canyon, Colo., from Waters ranch, at the junction of Weber and Mancos canyons; $C$, North end of Weber Mountain, Colo., from the lower slope of Menefee

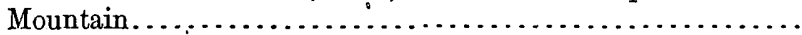

XXXVI. $A$, Lone Cone and Point Lookout, near Mancos, Colo., from the Government road; $B$, Cliff House sandstone and Spruce. Tree House, Mesa Verde, Colo. . ........................

XXXVII. Sections of the lower part of the Menefee formation, showing its

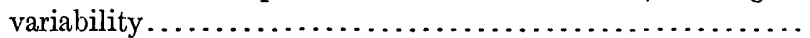

XXXVIII. Sections of Mesaverde coal beds, group A, near Mancos, Colo....

XXXIX. Sections of Mesaverde coal beds, groups B and C, near Mancos, Colo.

XL. Geologic map of the Lost Creek coal field, Morgan County, Utah.

XLI. Geologic map of Simi Valley, Ventura County, Cal. ............

XLII. Structure sections in Simi Valley, Cal....................

XIIII. Sketch map of Tapo oil field, Simi Valley, Cal. ..............

XLIV. Logs of wells of the Doheny-Pacific Petroleum Co. and the Hidalgo Oil Co. along an approximately north-south line across the Simi anticline, Simi Valley, Cal.....

FIGURE 1. Sections showing underground relations of rocks along Atchison, Topeka \& Santa Fe Railway between Strong and Ellinwood, Kans. ........................................

2. Section showing underground relations of rocks in plateau north of Arkansas River between Spearville and Mansfield, Kans....

3. Section showing underground relations of rocks along the Atchison, Topeka \& Santa Fe Railway between Garden City and Medway, Kans.

4. Diagram showing structure of Dakota sandstone in Syracuse and Lakin quadrangles, Kans. .........................

5. General section across Nebraska from Omaha to the Rocky Mountains.

6. Section along Republican Valley in southern Nebraska..........

7. Sketch section from Pine Ridge Agency, S. Dak., to Black Hills...

8. Columnar sections of sedimentary rocks underlying South Dakota...

9. Section from Black.Hills through Fall River County, S. Dak., to Pine Ridge, Nebr...............................

10. Section across central South Dakota from the Sioux quartzite region to the Black Hills.

11. Diagram showing structure under parts of Harding and Perkins counties, S. Dak

12. Section along Arkansas Valley from Pueblo to Canon City, Colo....

13. Section showing relations of wells in Arkansas Valley from Holly to Thatcher, Colo.

14. Diagram showing structure in the Apishapa quadrangle, Las Animas, Huerfano, Pueblo, and Otero counties, Colo............. 
Fraure 15. Map of the anticline on Old Woman Creek, Converse County, Wyo.

16. Section across the anticline on Old Woman Creek, Converse County,

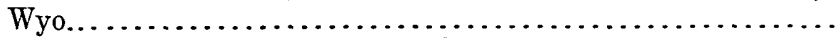

17. Ideal section to show relations of flexures in an older formation, under a monocline of younger rocks......................

18. Syncline in older strata persisting, although considerably flattened by a flexure that developed an anticline or dome in the overlying younger rocks....................................

19. Diagram illustrating processes of manufacture in the Scottish mineral-oil industry.

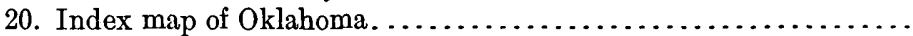

21. Hypothetical section illustrating the terracing in the northwestern part of the Pawhuska quadrangle, Okla.

22. Generalized stratigraphic section showing rocks exposed in northwestern part of Pawhuska quadrangle, Okla.

23. Cross section illustrating lenticularity of sandstone beds.

24. Sketch of rock fragment showing characteristic shapes of Cryptozoa in the Cryptozoon-bearing limestone.......................

25. Sketch illustrating conditions observed in railroad cut between Pearsons Switch and Blackland, Okla....................

26. Hypothetical cross section showing changes in the stratigraphy that would make observations on the outcrops of beds of small value.........................................

27. Cross section showing possible position of anticline below valley and of syncline below hill.

28. Sketch illustrating the importance of contouring lower bed rather than upper bed when determining structure...............

29. Structure contours representing a small anticline, based on 10 elevations.

30. Structure contours representing a small syncline, based on the same group of elevations that was used in figure $29 . \ldots \ldots \ldots . . . . .$.

31. Key map showing relation of Lake Basin field, Mont., to major structural features of the region.........................

32. Index map showing position of Birch Creek-Sun River area, Mont.

33. Columnar section of portions of Kootenai formation and Colorado shale..........................................

34. Diagram illustrating three types of structure produced by reverse dips on a monocline.

35. Index map showing location of the Salinas Valley-Parkfield

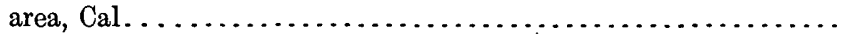

36. Geologic map of Pleyto oil district, Cal. . . . . . . . . . . . . .

37. Map showing general position of the Santo Tomas coal field, Webb County, Tex.

38. Sections showing general'stratigraphy of the Santo Tomas coal

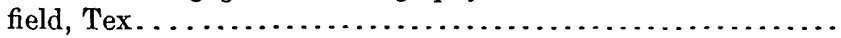

39. Detailed sections of rocks exposed in Santo Tomas aoal field, Tex., as measured in outcrop...............................

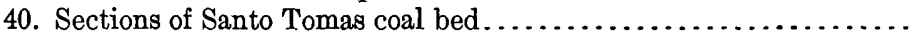

41. Sections of San Pedro coal bed.........................

42. Map of Colorado showing the location of the coal field south of Mancos, Montezuma County, and coal-mining centers in adjacent counties.

43. General view of the mountain tops near Mancos, Colo...........

44. Index map showing location of Lost Creek coal field, Utah......

45. Index map of a part of California, showing oil fields discussed in reports published by the United States Geological Survey..... 


\title{
CONTRIBUTIONS To ECONOMIC GEOLOGY, 1918.
}

\author{
PART II. MINERAL FUELS.
}

David White, G. H. Ashley, and M. R. Campbell, Geologists in charge.

\section{INTRODUCTION.}

- The Survey's "Contributions to economic geology" have been pubished annually since 1902. In 1906 the increase in the number of papers coming under this classification made it necessary to divide the contributions into two parts, one including papers on metals and nonmetals except fuels and the other including papers on mineral fuels. In 1915 the year included in the title was changed from the year in which the field work reported in these papers was done to the year of publication, and in consequence there was no volume entitled "Contributions to economic geology, 1914." The subjoined table gives a summary of these bulletins.

United States Geological Survey "Contributions to economic geology."

\begin{tabular}{|c|c|c|c|c|c|}
\hline Date in title. & $\begin{array}{c}\text { Date of } \\
\text { publica- } \\
\text { tion.a }\end{array}$ & $\begin{array}{l}\text { Bulletin } \\
\text { No. }\end{array}$ & Date in title. & $\begin{array}{c}\text { Date of } \\
\text { publica- } \\
\text { tion.a }\end{array}$ & $\begin{array}{c}\text { Bulletin } \\
\text { No. }\end{array}$ \\
\hline 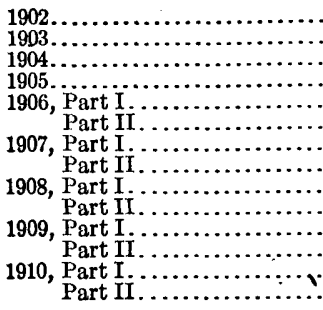 & $\begin{array}{l}1903 \\
1904 \\
1905 \\
1906 \\
1907 \\
1907 \\
1908 \\
1909 \\
1909 \\
1910 \\
1910 \\
1911 \\
1911 \\
1912\end{array}$ & $\begin{array}{l}213 \\
225 \\
260 \\
285 \\
315 \\
316 \\
340 \\
341 \\
380 \\
381 \\
430 \\
431 \\
470 \\
471\end{array}$ & 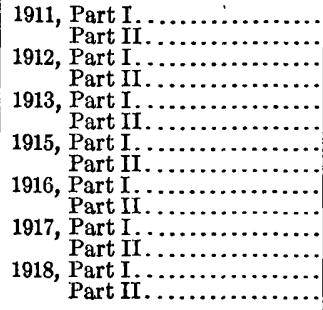 & $\begin{array}{l}1913 \\
1913 \\
1914 \\
1914 \\
1915 \\
1915 \\
1916 \\
1916 \\
1917 \\
1917 \\
1918 \\
1918 \\
1919 \\
1919\end{array}$ & $\begin{array}{l}530 \\
531 \\
540 \\
541 \\
580 \\
581 \\
620 \\
621 \\
640 \\
641 \\
660 \\
661 \\
690 \\
691\end{array}$ \\
\hline
\end{tabular}

$a$ The date given is that of the complete volume; beginning with Bulletin 285 the papers have been issued as advance chapters as soon as they were ready.

As the subtitle indicates, the papers included in these volumes are of two classes-(1) short papers giving comparatively detailed descriptions of occurrences that have economic interest but are not 
VIII CONTRIBUTIONS TO ECONOMIC GEOLOGY, 1918-PART II.

of sufficient importance to warrant a more extended description; (2) preliminary reports on economic investigations the results of which are published later in more detailed form. These papers are such only as have a direct economic bearing, all topics of purely scientific interest being excluded.

Brief abstracts of the publications of the year are given in the annual report of the Director. The complete list of Survey publications affords, by means of finding lists of subjects and of authors, further aid in ascertaining the extent of the Survey's work in economic geology.

The reports on work in Alaska have been printed in a separate series since 1904, the volumes so far issued being Bulletins 259, 284, $314,345,379,442,480,520,542,592,622,642$, and 662 . 